\title{
Curriculum Change and the Evolution of Postgraduate e-Business Subjects
}

\author{
Arthur Tatnall \\ Centre for International Corporate \\ Governance Research, Victoria \\ University, Melbourne, Australia
}

Arthur.Tatnall@vu.edu.au

Stephen Burgess

Centre for International Corporate

Governance Research, Victoria

University, Melbourne, Australia

Stephen.Burgess@vu.edu.au

\author{
Mohini Singh \\ School of Business \\ Information Technology, \\ RMIT University, Australia
}

Mohini.Singh@rmit.edu.au

Bill Davey

School of Business

Information Technology,

RMIT University, Australia

Bill.Davey@rmit.edu.au

\begin{abstract}
E-business courses were introduced in many universities around the world about ten years ago. Sometimes they were introduced at the undergraduate level, sometimes at postgraduate level and sometimes at both. This paper will present a case study examining the postgraduate e-business courses in two Australian universities and how they have changed over the last few years. The paper describes factors that influence the development of e-business courses and outlines atheory of subject development, originally intended to explain the development of new school subjects in $19^{\text {th }}$ century England. We make use of this theory to explain what has happened, and is still happening, in the case of e-business curriculum in Australia.
\end{abstract}

Keywords: E-business, e-commerce, university post graduate curriculum, curriculum change.

\section{Introduction}

About ten years ago many universities in Australia, and also around the world, began introducing new e-business subject matter and materials at both undergraduate and postgraduate levels. In some cases this represented complete courses in e-business, while in others cases individual subjects were added to existing courses. (In this paper we will use the term 'subject' in the Australian context to refer to an individual semester-length unit of study, and 'course' to mean a collection

Material published as part of this publication, either on-line or in print, is copyrighted by the Informing Science Institute. Permission to make digital or paper copy of part or all of these works for personal or classroom use is granted without fee provided that the copies are not made or distributed for profit or commercial advantage AND that copies 1) bear this notice in full and 2) give the full citation on the first page. It is permissible to abstract these works so long as credit is given. To copy in all other cases or to republish or to post on a serveror to redistribute to lists requires specific permission and payment of a fee. Contact Publisher@ InformingScience.org to request redistribution permission. of subjects that make up the award of a degree.) While undergraduate e-business courses need to provide a discipline base in computing and business on which the e-business content can be built, postgraduate e-business courses typically aim to provide additional 'top-up' material to information systems, general business or engineering graduates on how information and communication technologies (ICT) or e-business proc- 
esses might affect their work (T at nall, 2002).

In common with the technology it self, and in contrast with many other established disciplines, however, these courses have not remained static and have evolved considerably and at a fast rate overthis period. Perhaps the first thing to occur was a re-consideration of the name: e-Commerce versus $e$-Business. On a literal interpretation the term e-commerce is quite limited and could be used to refer only to financial transact ions on the Int emet. The term e-business, on the other hand, can be interpreted much more widely. Having said this though, many people also use the term ecommerce in a very wide sense and the same way that others use the term e-business. In this paper we will use the term e-business without meaning to preclude courses referred to as ecommerce.

At around the turn of the century, many e-business courses were developed in a short period of time and soon became very popular. Some people at the time, however, suggested that these courses would 'probably disappear in five years' (Melymuka, 2000). This supposition was based on two premises:

1. Firstly, that many of the concepts being taught specifically in e-business subjects would eventually be taught as part of common business subjects (for instance, e-Marketing concepts would become part of normal Marketing) and so there would be less need for specific e-business related skills (Wahl, 1999).

2. Secondly, that e-business represented the latest 'fad' and may disappear in time.

This did not happen, and this paper will begin with case studies examining the e-business subjects and courses at Victoria University and RMIT University, Australia. We will look at this material as it was first developed and at how it has changed over the years. We will then consider some theory relating to curriculum change and see how this fits with what we have observed in our courses.

\section{The E-Business Specialisation at Victoria University}

The postgraduate Electronic Business specialisation at Victoria University (VU) was introduced in 2002 as part of both an MBA and a Master of Business in e-Commerce and Marketing. (This postgraduate offering followed the earlier introduction of a Bachelor of Business in e-Commerce.) It was designed to prepare students for the management, application and use of e-business and related technologies. This was not a complete course, but a series of individual subjects that could be taken as part of one of these two courses. The specialisation covered issues relat ing to the Internet, intranets and extranets as well as use of the Internet as a business research and communications tool (Tatnall, Groom, \& Burgess, 2002). Initially, it consisted of three subjects: Intemet Commerce, Internet Technologies in Business and Building Internet Commerce Systems.

\section{Internet Commerce}

This introduct ory e-business subject was designed to provide an overview of how business is conducted over the Internet, along with the technological and infrastructure requirements and business and management issues relating to electronic business. The subject introduced the Internet and e-commerce practices and emerging trends and feat ures, with an overview of how business was conducted over the Internet.

\section{Internet Technologies in Business}

This subject aimed to examine ways that a business could use Internet technologies, as well as technologies such as intranets and firewalls to improve business processes and store business documents. It examined the use of intranets and extranets in business, the use of the Internet for 
business research, and the use of the Internet for business communication (T atnall, Groom et al. 2002). It s objective was to examine the ways that a business could use Internet technologies to improve its own business processes, find business information and improve communication by increasing the information richness of the communication and lowering communication costs. It endeavoured to introduce those areas of use of Internet technologies that were not taught in other specialisations, but are were used in the business world.

\section{Building Internet Commerce Systems}

The subject examined the use of HTML and other mark-up languages, design issues, scripting and programming for the Internet. It also covered topics such as Web databases, implementation options, and the fut ure of Internet design. The idea was to provide students with an understanding of the complexities of the design and development of Web sites for commercial environments. The subject proceeded through the levels of Web site design sophistication to the point where students would be expected to design user-friendly Web applications of relative complexity.

\section{Stage 2 - Later Developments at VU}

One challenge that then emerged for the course developers was the need to produce a specialisation that was available to students studying other courses. Most of these students were already studying Masters in Business programs with specialisations in the Information Systems field. As opposed to MBA graduates, these students are typically employed in fields such as business analysis, help-desk, information specialist, or as some type of technical specialist, and as such there was a need to provide students with a foundation in the areas of business and ICT. Ehie (2002) identified e-commerce as part of the discipline area of Management Information Systems, it also being recommended in a study for MIS business practitioners as a niche area for business schools. So, what areas should be included in the new subjects? The primary relationships in ebusiness occur between government, consumers and business. Within the business arena there are the various forms of business-to-business (B2B) relationships, and within individual businesses there are the use of intranets for internal business processes and decision-making.

In addition to this, the environment is clouded by the extensions that mobile commerce ( $\mathrm{m}$ commerce) will add to e-business functionality and the fact that now small and medium sized businesses (SMEs) are adopting Internet technologies at a rapid rate. SMEs, of course, lack the resources (time, expertise and capital) to implement e-business in as effective a manner as larger businesses (Burgess, 2002). With this view of the e-business marketplace in mind, it was determined that the best way in which to expand the offerings of the specialisation was to modify two existing masters subjects - Executive Computing and Building Small Business Systems that had previously been tailored to those specific areas of computing, and had gradually incorporated aspects of Internet technologies over recent years.

\section{Executive and mobile computing}

The purpose of this subject was to introduce students to information technologies that support managerial work and decision making, particularly the business executive away from the office and on the move, but needing to keep in touch. Topics covered included: executive information needs, decision making and decision support systems, group support systems, executive productivity tools, mobile executive computing - 'keeping in touch whilst on the move', executive information systems, knowledge management, integration and implementation of management support systems. Those mobile technologies that could interface with existing systems of the business were to be particularly emphasised. 


\section{Small business information and internet systems}

This subject introduced the student to a range of topics relating to ICT and Internet usage by small business. The idea was for the students to be able to build a small business system and advise on appropriate business use of the Internet. Topics covered included: the role of ICT and the Internet in small business, selecting applications for small business, integrating information and Internet systems with small business processes, selecting hardware and operat ing systems for small business, networking, building small business applications, office suite programming and integrating office and Internet applications.

\section{The Current Situation at VU}

Subse quent to the development of these subjects, the demand for e-business elective subjects from courses such as the Masters of Business in Information Systems increased. More recently, a Master of Business in E-Commerce has been introduced. This course includes all of these ebusiness subjects, along with a series of electives.

\section{E-Business at RMIT}

RMIT University introduced a postgraduate course in e-business in 2000, aimed at mat ure students with three years work experience. Like VU, this followed an excursion several years earlier into undergraduate e-business curricula. The Master of e-Business was offered in two formatsby coursework and by research, based on the assumption that there were many emerging electronic business issues that remained unresolved, and that growth potential in this area was enormous. Students in both the research and coursework programs were encouraged to undertake a project in conjunction with their company of employment. The course was generally delivered over weekends or during the evenings to minimise disruption to normal work demands for the students, who were offered a combination of lectures, present at ions, discussions, case studies, online discussions, tut orials and workshops. Collaborative work with students from overseas universities was also incorporated into some subjects. For the coursework program students would undertake eight core e-business subjects, three elective subjects and an industry project. The research version of the course was a hybrid coursework and research degree running over two years. The coursework subjects were to provide students with the required knowledge of the discipline and to reduce the time required for literat ure review.

\section{e-Business Frameworks}

This subject introduced issues prevalent in the e-business environment including an understanding of e-business, components of e-business and the way in which this has evolved and continued to develop, the impact of e-business on a single company and by extrapolation on industry more generally, and the identification of emerging issues in e-business. It also provided an understanding of technology as the enabler of e-business.

\section{e-Corporate Intelligence}

The aim here was to explore a range of issues associated with the management of strategic intelligence in the $21^{\text {st }}$ cent ury within the larger context of corporate knowledge. Intelligence plays a pivotal role in the process of creating new knowledge, which is essential for organisations to innovate and expand. It is a vital ingredient in shaping corporate strategy and is easily accomplished on the Internet. 


\section{B2B e-Business Applications}

$\mathrm{B} 2 \mathrm{~B}$ e-business is the largest segment of the Internet economy and this subject provided an overview of models, concepts and strat egic issues in relation to inter-organisational B2B online exchanges. It also covered emerging global B2B E-business applications enabled by B2B networks, e-procurement, e-markets, online bidding, reverse auctions, revenue models, e-market governance and forward and reverse supply chain issues.

\section{e-Business Law}

This examined the legal landscape that enabled e-business, providing an understanding of how the law has reacted to developing computer technology and its use in the conduct of business. Legal issues in relation to e-business such as the impact of copyright, trademark and trade secret laws, contract and jurisdictional concerns, digital signat ures, privacy and intellectual property rights made up the major component of this subject.

\section{e-Marketing}

The impact of the Internet on marketing and advertising was examined and discussed. Particular emphasis was given to the role of the Web in the current, and fut ure integrated market ing communication, customer fulfilment strategy and customer relationship management (CRM). Other emarketing issues explored included the e-marketing structure, staffing, systems and resources.

\section{e-Supply Chain Management}

This subject addressed the concept of supply chains and logistics management within e-business. Emphasis was on the import ance of logistics and the impact of technology for tracking goods delivered. It also addressed the relationship and linkages bet ween logistics and other functional areas of management.

\section{e-Business Technology}

The technological infrastructure requirements for an e-business solution were examined here. The subject explored the role of the Internet and associated technologies as a strategic resource for ebusiness. Also explored were: the impact of networks, communicat ion protocols, server platforms, electronic communication tools, bandwidth and security, and their implications on ebusiness. Technological developments and resulting e-business innovations were also discussed.

\section{Managing the Networked Enterprise}

This subject discussed the relationship between the practice of contemporary strat egic management and e-business in a computer net worked, global context. It specifically focussed on the practice of strat egic thinking, strat egic planning, innovation and strat egic change, entrepreneurship, leveraging e-business networks effectively, and understanding the dynamics between economic development and the growth of new businesses. Issues common to small, medium and large enterprises and those issues unique to the "net worked enterprise" in each sect or was discussed.

\section{Economics of Information and Networks}

This subject applied standard microeconomic analyses to the continuously changing area of information products and infrastructure to provide students with analytical skills to assist them in making strategic choices involving information goods and technology. It examined costs of producing information and market structures for information goods using economic tools to critically 
examine alternatives for pricing and versioning information goods and technology choice. It also addressed the implications of standards for information products and technologies.

\section{e-Business Trends and Directions}

E-business evolves with new developments in technologies, partnerships, business methods and environmental changes resulting in new business trends, issues and challenges. This subject explored a range of rapidly changing contemporary issues as it addressed new developments in ebusiness. New business models, enabling infrastructure developments, e-business processes, integration and engineering requirements, the e-business environment and its implications for the future were explored.

\section{e-Business Project}

A prerequisite for this subject was that all core subjects had been successfully completed. In this subject students undertook and completed an industry project under the guidance of a faculty mentor. The project dealt with topics in the area of e-business that were of significant value to business and students were encouraged to undertake and complete a project with their employer. Other industry-sponsored projects within the E-Business group were also made available to students.

\section{Minor Thesis Option}

As an alternate option, students were able to subst it ute three subject electives and the final project for a minor thesis. Thesis topics were selected jointly by students and supervisors and students were encouraged to choose topics relevant to e-business.

\section{e-Business Curriculum Issues at RMIT}

At RMIT University this course had been introduced by a high profile professor of e-business, and this helped increased enrolments at the inception of the program. The first cohort of students enrolled was well qualified, holding senior positions in organisations generally around the Melbourne central business district. However, this professor then left the university in somewhat of a hurry, leaving only a few academics with e-business knowledge to deliver the program. Most other academicsteaching into the course were from the general business area and without a technology background. Most also did not undertake research in the area of e-business. The teaching of these subjects was thus focussed on basic business iss ues that were also taught in other courses. Another problem was that the sequence in which the subjects were offered did not facilitate progressive learning.

The students soon realised they were not getting what they had hoped for and the numbers reduced significantly. Many opted for the earlier exit point of a graduate certificate or a graduate diploma. Attracting new students to this course was also difficult and the situation was worsened by the dot.com crash. As a result, the university abandoned this program and included relevant subjects ( $e$-Business Trends and Issues that became $e$-Business Models and Issues, Managing the Networked Enterprise, e-Business Technologies, and B2B e-Business that became e-Procurement and e-Markets) into another postgraduate course: the Master of Business Information Technology. The research program was changed to a full research masters program resulting in a lot more research students exploring e-business issues.

\section{Factors Affecting E-Business Curriculum Change}

As it involves interactions between people and technology, e-business curricula must be considered in a socio-technical context. All curriculum change is complex, but e-business curriculum 
development is particularly so due to the rapidity of technological change, and also to the multitude of interested parties involved. Figure 1 highlights the many factors involved.

It is quite uncontroversial to say that technological change is progressing at a great rate, and that

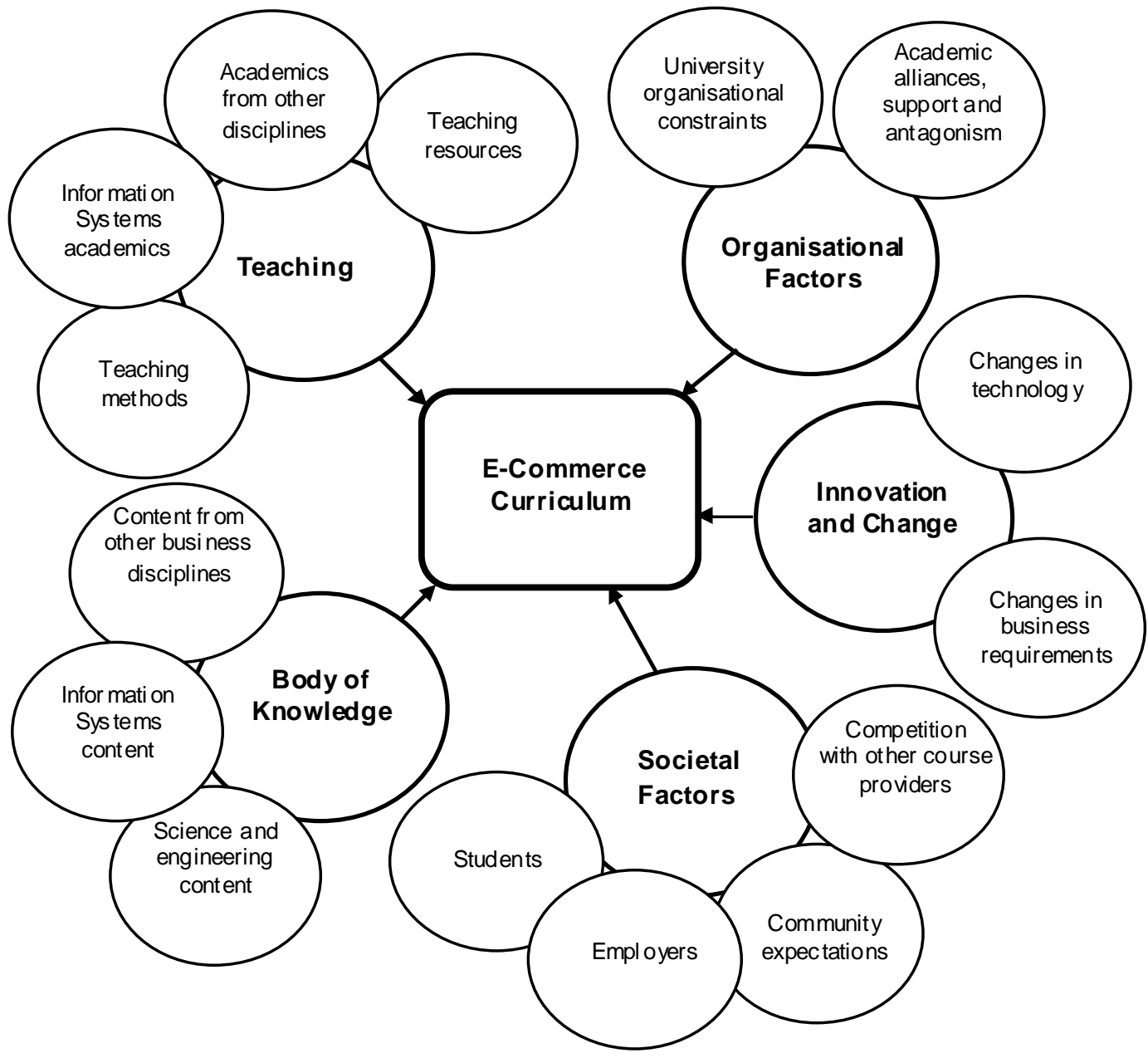

Figure 1: Details of Factors Inf luencing the Development of E-B usiness Curriculum (Tatnall, 2002)

we need to take this into account in our curriculum development. Many Information Systems (IS) curriculum developers (Cougar, Davis, Gorgone, Feinstein, \& Longenecker 1995; Longenecker, Feinstein, Cougar, Davis, \& Gorgone 1994; Nunamaker. 1981) argue that IS is a technologydriven field and that emergent technologies are an important dynamic force in its development. Clearly this must also be true of e-business curriculum.

Whether the existence of a new technological entity it self is a cause for change, or whether change occurs as a result of people's interaction with technology, has been the subject of much philosophical debate (Callon, Law, \& Rip, 1986; Collins \& Yearley, 1992).

In many ways e-commerce curriculum in the early $21^{\text {st }}$ century can be compared to computer science curriculum in the 1960s or information systems curriculum in the 1970s (Tatnall, 1994, 2006) where curriculum needed to change frequently to keep up with changes in technology. It was necessary for these curricula to 'keep up' as the fundamentals of these disciplines were then still being determined (Tatnall, 2002). When it is not completely clear what is fundamentally im- 
portant in any curriculum area we tend to teach what is new. E-business curriculum development around the world, we suggest, recently went through this stage.

\section{Layton's Model of Curriculum Development}

In attempting to describe the evolution and development of new school subjects in nineteenth century England, Layton (1972) proposed a three-stage model. In line with this model, the evolution of the school subjects he investigated occurred slowly, Geography for example, taking over 80 years to achieve its current form. Layton's model has been shown to be useful in examining this kind of slow subject evolution, and Tatnall (2006) has shown that limited use can be made of some aspects of this model in describing the rapid emergence and evolution of curricula in Information Systems. Layton defined three stages in this subject evolution:

In the first stage: the callow intruder stakes a place in the timetable, justifying its presence on grounds such as pertinence and utility. During this stage learners are attracted to the subject because of its bearing on matters of concern to them. The teachers are rarely trained specialists, but bring the missionary enthusiasms of pioneers to their task. The dominant criterion is relevance to the needs and interests of learners.

In the interim second stage: a tradition of scholarly work in the subject is emerging along with a corps of trained specialists from which teachers may be recruited. Students are still attracted to the study, but as much by its reputation and growing academic status as by its relevance to their own problems and concerns. The intemal logic and discipline of the subject is becoming increasingly influential in the selection and organisation of subjectmatter.

In the final stage: the teachers now constitute a professional body with established rules and values. The selection of subject matter is determined in large measure by the judgements and practices of the specialist scholars who lead inquiries in the field. Students are initiated into a tradition, their attitudes approaching passivity and resignation, a prelude to disenchantment.

(Layton 1972)

Layton was, however, investigating school subjects such as Geography in $19^{\text {th }}$ century England not university e-business subjects in the $21^{\text {st }}$ century in Australia, but we suggest that this model has much to offer here just the same. Layton (1972) describes the first stage of curriculum development in which enthusiasticteachers bring "missionary enthusiasm" to theirtask, and justify the new subject on grounds of "pertinence and utility". Tat nall $(1993,2006)$ argues that this was also true of the growth of Information Systems curriculum in the 1970s and 1980s. Could this not also be said of those introducing e-business courses in the $21^{\text {st }}$ century?

Layton argues that evolution then occurs into a second stage where a tradition of "scholarly work" emerges and trained teachers take over the delivery of the subject. Greater thought is given to the selection and organisation of subject matter sothat this is consistent with the "internal logic and discipline" of the new subject, ratherthan just being useful. This also seems to fit with current e-business curriculum development. Layton's third stage implies complete standardisation, even approaching stagnation, where subject content is determined largely by specialist scholars. This is not done on any basis of utility. E-business curriculum has certainly not reached this stage as yet, and it is questionable whether it ever will.

\section{Change in E-Business Subjects at Victoria University}

In the first three e-business subjects introduced at Victoria University there was little formal change in the sense of new handbook entries. There was, however, a great deal of change in the 
stress placed on different topics, the depth of coverage, the materials and resources, and the methods of teaching. In other words, there was considerable change in what was actually taught. In what follows we will use one of these subjects: Internet Technologies in Business, as an example of how the curriculum within each subject has changed over the last five years.

Internet Technologies in Business has now been taught eight times in Melbourne and six times at our sister university in Beijing. T wo of the authors of this paper have undertaken most of this teaching. While each of us had spent sometime as Directors of the University's Electronic Commerce Research Unit and had done some e-business research, when we launched the subject we certainly did not regard ourselves as experts in this area. Although not novices at e-business when we commenced teaching this subject we certainly had to feel our way carefully in working out what to include and at what level to teach it. As suggested in Layton's first stage, the subject was initially justified on the grounds of utility - it was something that IS and other post graduate students should know about. As there were few relevant teaching materials we quickly worked on putting together our own textbook (Davison, Burgess, \&T at nall, 2003) so that the students could have something other than our lectures to rely on. Initially we were not able to include much theory or intellectual framework, and most of the teaching was about the technology itself and our ideas, supplemented by our reading, on how it might be used. Delivery of the subject was initially very practical, with a lot of time spent looking at web sites, examining technology specifications and reading case studies. This clearly fits in well with Layton's first stage of subject development.

Over the years, however, we have been able to add more of a theoretical framework to the subject. One example of this is in the area of facilitating business communications where we have included Keen and Cummins' (1994)Telecommunications Services Platform Map to identify an organisation's technical capabilities in relation to three dimensions of business: reach, range and responsiveness. We have begun moving into Layton's second stage, but have not moved into this stage fully as yet. Later we became more confident with the subject material and experimented with setting up joint assessment tasks between Australian and Chinese students to illustrate collaboration using the Internet. It is doubtful if this subject will ever reach Layton's third stage as before that begins to happen some new technology, business process or idea will probably emerge and the subject change fundamentally again and the curriculum development process will return to an earlier stage!

\section{Change in E-Business Subjects at RMIT University}

At RMIT the first set of subjects included in the postgraduate course were seen to be relevant, mainly as all had an 'e' att ached to theirtitle. However, most of the teachers were neither knowledgeable in the emerging issues of their topic area, nor were they doing any research in this area. The subjects were relevant (Layton, 1972) as an import ant innovation and application of ICT in business and the benefits of e-commerce created a lot of interest amongst students.

The interim stage of this course at RMIT did not quite satisfy Layton's description of course development as it could not attract students to enrol. Other problems were the lack of background knowledge of most of the teachers which created a negative reputation. Although research in this area by a few academics increased and this directly informed teaching, by then the course it self had lost its reputation and could not attract students. The subjects taught were thus modified to reflect emergent issues in e-business, and included in another postgraduate course. Largely due to the Internet and e-business, enterprises have become more net worked and this requires new management structures, people and processes. A subject involving the management of these new types of organisations was thus developed. Electronic dat a interchange (EDI) and interorganisational systems aspects of the B2B subject were replaced by online bidding on e-markets for electronic procurement of raw materials, stationery, travel and other requirements, and the 
subject's name changed to e-Procurement and e-Markets. Due to the growing importance of ontology for existing and emerging models in e-business, the subject e-Business Trends and Issues was changed to one that addressed e-Business Models and Issues.

Although research and publications on e-business have increased around the world and newer topics emerged almost daily, due to the rapid changes in technology supporting e-business it is not possible for any single set of theories to be taught in e-business. It is thus still not really clear that the fundamentals have been determined. For e-business curricula at RMIT, Layton's final stage, or perhaps even his full second stage have not been achieved as yet.

\section{Conclusion}

Courses and individual subjects in e-business in the two universities discusse d have mat ured over the last ten years, changing from the highly practical and utilitarian to something better developed, and based on a more substantial theoretical framework. In any new area it takes some time before the fundamentals become clear and this is only starting to happen with e-business. Of course somethings have been apparent from the beginning, but which of these are really ideas that come from Information Systems, Management, Marketing or some other business area is only now becoming apparent as the discipline of e-business mat ures. In this paper we have examined case studies of the post graduate e-business offerings from two Australian universities and looked at some of the ways in which they have changed over the last few years. This evolution can be related, at least to a degree, to the model proposed by Layton, and we suggest that this offers a useful starting point for the discussion of new and evolving curriculum areas.

For the practitioner involved in curriculum design, Layton's idea that a new subject area begins with the practical and moves from there towards the theoretical is an interesting one. In our experience this model was useful in explaining the development Information Systems curriculum in the 1970s and 1980s as well as the more recent development of e-business curriculum. If we reflect on the way that we taught something the first time around and compare this with the way we teach it now, many of us will be able to relateto this model.

\section{References}

Burgess, S. (2002). Inform ation technology in small business: issues and challenges. In S. Burgess, Information technology and small business: issues and challenges (pp. 1-17). Pennsylvania, USA: Idea Group.

Callon, M., Law, J., \& Rip, A. (Eds.). (1986). Mapping the dynamics of science and technology. Sociology of science in the real world. Basingstoke: Macmillan Press.

Collins, H. M., \& Yearley, S. (1992). Epistemological chicken. In A. Pickering, Science as practice and culture (pp. 301-326). Chicago, IL: Chicago University Press.

Cougar, J. D., Davis, G. B., Gorgone, J. T., Feinstein, D. L., \& Longenecker, H. E. (1995). Information systems IS'95 DRAFT report. Model curriculum and guidelines for undergraduate degree programs in information systems. USA, AIS, ACM, DPMA.

Davison, A., Burgess, S., \& Tatnall, A. (2003). Internet technologies and business. Melbourne, Data Publishing.

Ehie, I. C. (2002). Developing a management information systems (MIS) curriculum: Perspectives from MIS practitioners. Journal of Education for Business, 77(3), 151-157.

Keen, P. G. W., \& Cummins, J. M. (1994). Networks in action: Business choices and telecommunications decisions. USA, International Thomson Publishing.

Layton, D. (1972). Science as general education. Trends in Education (January). 
Longenecker, H. E., Feinstein, D. L., Cougar, J. D., Davis, G. G., \& Gorgone, J. T. (1994). Information systems '95: A summary of the collaborative IS curriculum speci fication of the joint DPMA, ACM, AIS task force. Journal of Information Systems Education. Winter 1994-95, 174-186.

Melymuka, K. (2000). Mastering e-commerce by degrees. Computerworld, 34, 48-49.

Nunamaker, J. F. E. (1981). Educational programs in information systems: A report of the ACM Curriculum Committee on Inform ation Systems. Communications of the ACM, 24(3), 124-133.

Tatnall, A. (1993). A curriculum history of business computing in Victorian tertiary institutions from 1960 1985. MA thesis: Education. Geelong, Deakin University.

Tatnall, A. (1994). The beginnings of business computing. Asia Pacific In formation Technology in Training and Education, Brisbane, APIT ITE-94 Council.

Tatnall, A. (2002). Socio-technical processes in the development of electronic commerce curricula. In A. Wenn, Skilling the e-business professional (pp. 9-21). Melbourne, Heidelberg Press.

Tatnall, A. (2006). Curriculum cycles in the history of information systems in Australia. Melbourne, Heidelberg Press.

Tatnall, A., Groom, C., \& Burgess, S. (2002). Electronic commerce specialisations in MBAs: An Australian university case study. Informing Science and IT Education Conference, Cork, Ireland, University College Cork. Retrieved from http://proceedings.informingscience.org/IS2002Proceedings/papers/Tatna087el ect.pdf

Wahl, A. (1999). Out on the bleeding edge. Canadian Business, 72(17).

\section{Biographies}

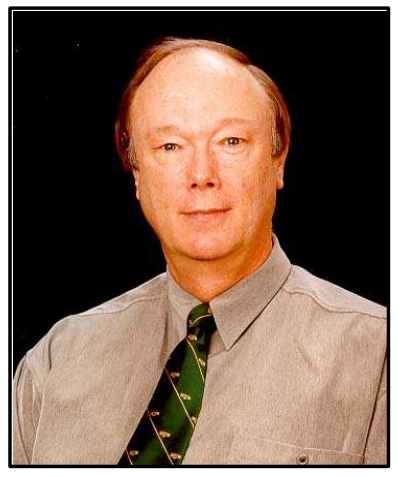

Arthur Tatnall is an Associate Professor in the Graduate School of Business at Victoria University in Melbourne, Australia. He holds bachelors degrees in Science and Education, a Graduate Diploma in Computer Science, and a research Master of Arts in which he explored the origins of Information Systems curriculum in Australian universities. His PhD involved a socio-technical study in curriculum innovation in which he investigated the manner in which Visual Basic entered the curriculum of an Australian university. His research interests include technological innovation, history of technology, information systems curriculum, project management, electronic commerce, and information technology in educational management. He has just completed editing the Encyclopedia of Portal Technology and Applications.

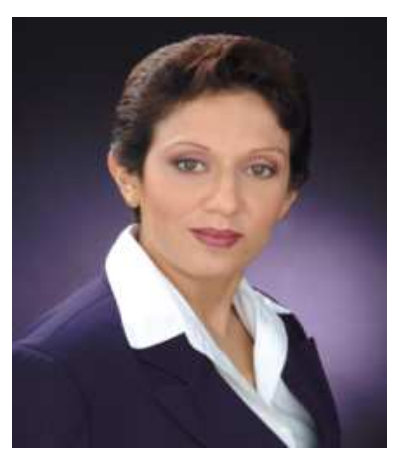

Mohini Singh is Professor of Information Technology and Digital Business in the School of Business Information Technology at RMIT University. The focus of her research is on the application of Information Technology to real world problems underpinned by social science theories and innovative data collection methods. Her track record includes research on Information Technology, E-Business and EGovernment; outcomes of which have resulted in journal publications, book chapters and international conference proceedings. Her research outcomes reflect methodology development and application-oriented results in the discovery and creation of new knowledge in the areas of Information Systems, Information Technology Management, E-

Business and E-Government. She is currently working on a research project evaluating the impact of e-government on rural citizens, funded by the Rural Industries Research and Development 
Corporation; and a collaborative research project on e-administration with academics from the Institut national des telecommunications in France, funded by the Academy of Social Science and the French Embassy. Professor Singh is well recognised for her research and curriculum development experience in the area of E-Business. She has delivered keynote addresses at international forums and to the Parliament of Victoria for policy development on telecommunications infrastructure for business in rural Victoria.

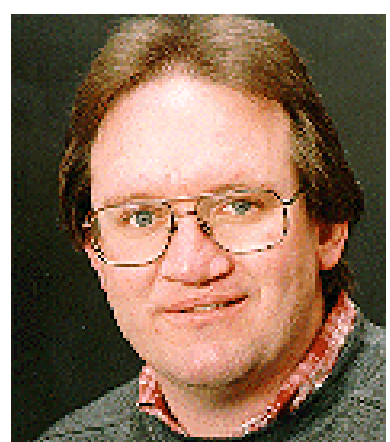

Dr Stephen Burgess is a Senior Lecturer in the School of Information Systems at Victoria University, Melbourne, Australia. He has a bachelors degree in Accounting and a Graduate Diploma in Commercial Data Processing, both from Victoria University, Australia; a Master of Business (Information Technology) from RMIT, Australia and a PhD from Monash University, Australia in the area of small business to consumer interactions on the internet. His research and teaching interests include the use of IT in small business, the strat egic use of IT, B-C electronic commerce and IT management education. He was formerly the Director of the Electronic Commerce Research Unit at Victoria University and is currently convener of the IRMA Special Research Cluster on Small Business and Information Technology (www.business.vu.edu.au/sbirit).

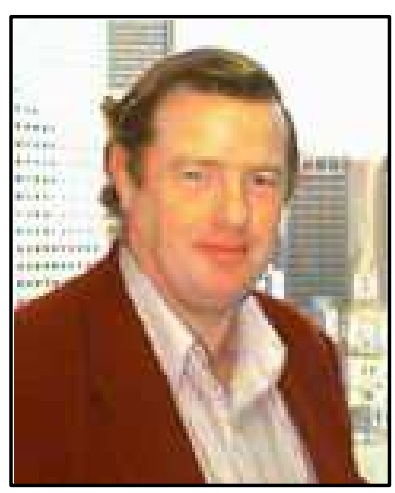

Bill Davey is a Senior Lecturer in the School of Business Information Technology at RMIT University, Melbourne, Australia. He holds bachelors degrees in Science and Education, a Graduate Diploma in Computing, and Master of Business degree. His research interests include methodologies for systems analysis and systems development, Visual Basic programming, information systems curriculum, and information technology in educational management.

Arthur and Bill have worked together co-operatively on many occasions. They have co-operated on several joint research projects and coauthored a large number of academic papers, book chapters, and textbooks relat ing to management information systems, programming, computers in management, and IS curriculum. 